\title{
Nocardia coubleae sp. nov., isolated from oil-contaminated Kuwaiti soil
}

Correspondence

Verónica Rodríguez-Nava veronica.Rodriguez@sante. univ-lyon 1 .fr

\author{
Verónica Rodríguez-Nava, ${ }^{1,2,3,4}$ Z. U. Khan, ${ }^{5}$ Gabriele Pötter, ${ }^{6}$ \\ Reiner M. Kroppenstedt, ${ }^{6}$ Patrick Boiron ${ }^{1,2,3,4}$ and Frédéric Laurent ${ }^{1,2,3,4}$ \\ ${ }^{1}$ Research group on 'Bacterial Opportunistic Pathogens and Environment', Université de Lyon, \\ F-69003 Lyon, France \\ ${ }^{2}$ Université Lyon 1 and CNRS, UMR 5557, Ecologie Microbienne, F-69622 Villeurbanne, \\ France \\ ${ }^{3}$ Institut des Sciences Pharmaceutiques et Biologiques, F-69373 Lyon, France \\ ${ }^{4}$ Observatoire Français des Nocardioses, F-69373 Lyon, France \\ ${ }^{5}$ Department of Microbiology, Faculty of Medicine, Kuwait University, Kuwait \\ ${ }^{6}$ Deutsche Sammlung von Mikroorganismen und Zellkulturen, Braunschweig, Germany
}

\begin{abstract}
Two bacterial isolates from Kuwaiti soil contaminated by crude oil were analysed by using a polyphasic taxonomic approach. The isolates, designated OFN N11 and OFN N12 ${ }^{\top}$, were shown to have molecular, chemical and morphological properties typical of members of the genus Nocardia. Based on a multigenic approach that included 16S rRNA, hsp65 and sod gene sequencing, these novel isolates formed a monophyletic clade within the genus Nocardia. The closest species was Nocardia ignorata (with 99.4\%, 99.5\%, 98.6\% gene sequence similarity to the 16S rRNA, hsp65 and sod genes, respectively). The novel isolates could be distinguished phenotypically from the type strains of recognized species of the genus Nocardia. The novel isolates were not related to the type strain of $N$. ignorata in DNA-DNA hybridization experiments (26\% relatedness). On the basis of these genotypic and phenotypic data, the two isolates appear to represent a novel species, for which the name Nocardia coubleae sp. nov. is proposed. The type strain is OFN N12 ${ }^{\top}\left(=\mathrm{DSM} 44960^{\top}=\mathrm{CIP} 108996^{\top}\right)$.
\end{abstract}

Bacteria belonging to the genus Nocardia were first isolated in 1888 by the French veterinarian Edmond Nocard (Nocard, 1888). This genus is a member of the family Nocardiaceae and the order Actinomycetales (Stackebrandt et al., 1997). During the last ten years, with the advent of molecular phylogenetic techniques, the genus Nocardia has undergone a taxonomic revolution (Roth et al., 2003). At the time of writing, 40 species have so far been isolated from human and animal samples and 23 species have been isolated from environmental samples (http://www.bacterio. cict.fr/n/nocardia.html). During a taxonomic re-evaluation of environmental and human strains deposited in the culture collection of the French Nocardiosis Observatory

\section{Abbreviation: OFN, French Nocardiosis Laboratory.}

The GenBank/EMBL/DDBJ accession numbers for the $16 \mathrm{~S}$ rRNA, hsp65 and sod gene sequences of strains N11 and $N 12^{\top}$ are DQ250024, DQ235689, DQ25025, DQ235688, DQ683744 and D0683745, respectively.

Additional phylogenetic trees based on analysis of the 16S rRNA, hsp65 and sod gene sequences are available as supplementary figures with the online version of this paper.
(OFN, Lyon, France), we comprehensively investigated the taxonomic position of two selected strains, OFN N11 and OFN N12 ${ }^{\mathrm{T}}$. An integrated approach was used based on molecular, chemotaxonomic and phenotypic methods.

The two novel strains were isolated in 1997 from soil from the Ahmadi oilfield which had been contaminated with crude oil during the Gulf war. The paraffin bait technique used to isolate these micro-organisms was first described by Kurup \& Schmitt (1971). The novel strains were initially identified as Nocardia asteroides by using basic physiological methods (Khan et al., 1997). Following this initial identification, the isolates were sent to the OFN by the Microbiology Department of Kuwait University for accurate identification. The strains were maintained as glycerol suspensions $(20 \%, \mathrm{v} / \mathrm{v})$ at $-20{ }^{\circ} \mathrm{C}$. Growth was achieved on Bennett's agar at $37^{\circ} \mathrm{C}$. On this agar, both isolates were able to grow at temperatures between 25 and $37^{\circ} \mathrm{C}$. The orangecoloured substrate mycelium was well-developed, with irregular branches penetrating the agar and bearing sparse white aerial hyphae. The cells were Gram-positive and acidfast as determined by a modified Ziehl-Neelsen method ( $1 \%$ acid decoloration). 
Several molecular methods were used to characterize the two isolates. Their affiliation to the genus Nocardia was confirmed by genus-specific $16 \mathrm{~S}$ rRNA gene amplification (Laurent et al., 1999). Hsp65 polymorphism analysis (Steingrube et al., 1997) yielded a restriction pattern (BstEII 320 and 80 bp, MspI 130, 120, 115 and 70 bp and HinfI 250 and $190 \mathrm{bp}$ ) that was identical to that found for Nocardia ignorata (Rodriguez-Nava et al., 2005).

A multigene sequencing approach was then applied. Part of the 16S rRNA gene (around 1322 nucleotides, corresponding to positions 46-1400 of the Escherichia coli numbering system) of strains OFN N11 and OFN N12 ${ }^{\mathrm{T}}$ was amplified by using primers SQ1 (5'-AGAGTTTGATCMTGGCTCAG-3') and SQ6 (5'-CGGTGTGTACAAGGCCC-3') as described by Rodríguez-Nava et al. (2004). A partial hsp65 gene sequence ( $65 \mathrm{kDa}$ heat-shock protein, 441 nucleotides corresponding to positions 396-836 of Mycobacterium tuberculosis CIP 105795) was amplified by using primers TB11 (5'-ACCAACGATGGTGTGTCCAT-3') and TB12 (5'-CTTGTCGAACCGCATACCCT- $3^{\prime}$ ) as described by Rodríguez-Nava et al. (2006) and a partial sod gene sequence (superoxide dismutase, 442 nucleotides corresponding to positions 82-523 of Nocardia farcinica IFM 10152) was obtained with primers Z205 (5'-ACGTTCACCACAGCAAGCACCA-3') and Z212 (5'-TCGGCCCAGTTCACGACGTT- $3^{\prime}$ ) for the two test strains and for ten Nocardia type strains with similar $16 \mathrm{~S}$ rRNA genes ( $N$. ignorata, Nocardia soli, Nocardia cummidelens, Nocardia salmonicida, Nocardia fluminea, N. asteroides, Nocardia brasiliensis, Nocardia uniformis, Nocardia cyriacigeorgica and Nocardia tenerifensis) as described by Devulder et al. (2005).

The PCR products were purified by using a Microspin Gel Extraction kit (Omega, Bio-tek) and sequenced on both strands by using the same primers, the Taq Dye Deoxy terminator cycle sequencing kit (Applied Biosystems) and a DNA sequencer (model 373A; Applied Biosystems). For phylogenetic analysis, the nucleotide sequences (excluding the primers) were aligned with the corresponding sequences of representative Nocardia species from the GenBank database and the BIBI database (Devulder et al., 2003) by using CLUSTAL_X (Thompson et al., 1997).

The phylogenetic trees were constructed with the MEGA (Kumar et al., 2004) and PHYLO_WIN (Galtier et al., 1996) software packages with three treeing algorithms, namely the maximum-likelihood (Felsenstein, 1981), maximum-parsimony (Fitch, 1971) and neighbour-joining (Saitou \& Nei, 1987) methods. The tree topology was determined by using 1000 bootstrapped datasets.

Strains OFN N12 ${ }^{\mathrm{T}}$ and OFN N11 shared identical sequences for all three of the genes examined. The closest relative of strains OFN $\mathrm{N}_{12}{ }^{\mathrm{T}}$ and OFN N11 was $N$. ignorata DSM $44496^{\mathrm{T}}$, showing $99.4 \%$ sequence similarity (8 nucleotide differences out of $1322 \mathrm{nt}$ ) for the $16 \mathrm{~S}$ rRNA gene (Fig. 1 and Supplementary Fig. S1 in IJSEM Online), 99.5\% sequence similarity (2 differences out of $401 \mathrm{nt}$, excluding the primers) for the $h s p 65$ gene (see Supplementary Fig. S2 in IJSEM Online) and $98.5 \%$ sequence similarity (6 differences out of $406 \mathrm{nt}$, excluding the primers) for the sod gene (see Supplementary Fig. S3 in IJSEM Online). Smaller sequence similarities were found with the other species of the genus Nocardia. On the basis of the $16 \mathrm{~S}$ rRNA and $h s p 65$ gene sequences, phylogenetic analysis showed that the two novel isolates matched the $N$. salmonicida subclade $(N$. cummidelens, $N$. fluminea, $N$. ignorata, $N$. salmonicida and N. soli) (Maldonado et al., 2000). In contrast, this specific subclade was not recognized when the sod gene sequences were analysed (see Supplementary Fig. S2). Regardless of which of the three genes was considered, $N$. ignorata was the closest species phylogenetically with bootstrap values of 98 , 100 and 100, respectively, for the 16S rRNA, hsp65 and sod genes (See Supplementary Figs S1-S3). These results demonstrate that strains OFN N12 ${ }^{\mathrm{T}}$ and OFN N11 form a distinct phyletic line within the genus Nocardia.

Strain OFN N12 ${ }^{\mathrm{T}}$ was characterized chemotaxonomically and the results supported its assignment to the genus Nocardia. Cell-wall composition was investigated using TLC as described by Boiron et al. (1993). For strain OFN N12 ${ }^{\mathrm{T}}$, the cell-wall peptidoglycan contained meso-diaminopimelic

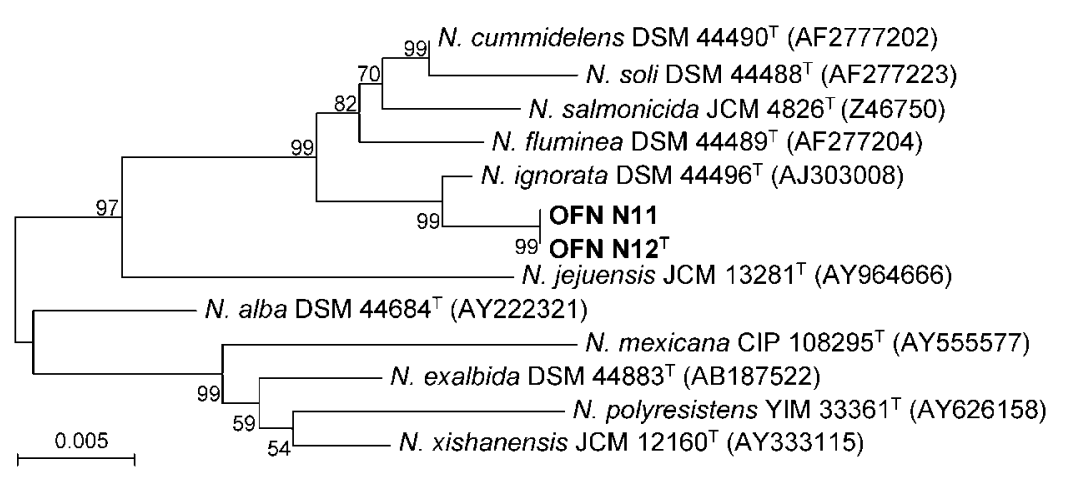

Fig. 1. Phylogenetic tree derived from $16 \mathrm{~S}$ rRNA gene sequences showing the relationships between $N$. coubleae sp. nov. strains OFN $N 12^{\top}$ and OFN $\mathrm{N} 11$ and species belonging to the genus Nocardia. The tree was constructed by using the neighbourjoining method and was based on a comparison of 1322 nucleotides. Bootstrap values were expressed as a percentage of 1000 replications. Bar, 0.005 substitutions per nucleotide position. An extended version of this tree including a wider selection of reference strains is available as a supplementary figure (see Supplementary Fig. S1 available in IJSEM Online). 
acid as the diagnostic diamino acid. Analysis of whole-cell hydrolysates yielded arabinose, galactose, glucose and ribose.

Standard analyses of fatty acids, mycolic acids and isoprenoid quinones were performed by means of HPLC and were interpreted as described by Kroppenstedt with the standard Microbial Identification System (MIDI) for automated GC analysis (Kroppenstedt, 1982, 1985; Minnikin et al., 1975, 1984). The analyses revealed the presence of mycolic acids with a chain length of 52-58 carbon atoms (the principal mycolic acids have a chain length of 56 carbon atoms) as expected for members of the genus Nocardia (C50-C62). The fatty acid content was $\mathrm{C}_{18: 0}(16.0 \%), \mathrm{C}_{18: 1}$ (6.5\%), $\mathrm{C}_{17: 0}(3.8 \%), \mathrm{C}_{15: 0}(1.7 \%), \mathrm{C}_{17: 1}(1.5 \%), \mathrm{C}_{14: 0}$ $(1.1 \%), \mathrm{C}_{15: 1}(0.3 \%)$ and $\mathrm{C}_{10: 0}(0.1 \%)$ and the main fatty acids were palmitic acid $\left(\mathrm{C}_{16: 0}, 27.2 \%\right)$, palmitoleic acid $\left(\mathrm{C}_{16: 1}, 20.22 \%\right)$ and tuberculostearic acid (10 methylbranched $\left.\mathrm{C}_{18: 0}, 19.8 \%\right)$. The main menaquinone $(74.2 \%)$ was MK- $8\left(\mathrm{H}_{4 \mathrm{cycl}}\right)$ and small amounts of MK- $8\left(\mathrm{H}_{2}\right)(5.6 \%)$ and MK- $8\left(\mathrm{H}_{4}\right)(8 \%)$ were also detected.

The two novel isolates were also characterized phenotypically. The methods used for biochemical tests have been described previously (Boiron et al., 1993; Goodfellow, 1992, 1998). The ability to grow on various carbon sources was tested according to the methods of Goodfellow \& Lechevalier, 1989 and Boiron et al., 1993 and by using the API $50 \mathrm{CH}$ (bioMérieux) system according to the manufacturer's instructions. The API $50 \mathrm{CH}$ strips were utilized for only the type strain of $N$. ignorata and strains OFN N11 and OFN N12 ${ }^{\mathrm{T}}$. Inocula were standardized to obtain a final concentration of $1 \times 10^{4}-1 \times 10^{5}$ c.f.u. and were then suspended in API 50 CHB broth (bioMérieux). Tests were read daily, with a final reading taken at 4 days. Incubation beyond 4 days gave weak reactions in many wells that were interpreted as non-specific. Only the assimilation results were considered for the API $50 \mathrm{CH}$ system as oxidation and fermentation reactions were weak and difficult to interpret. Sugar assimilations in the API $50 \mathrm{CH}$ system were read as positive when heavy growth in the wells obscured the underlying stripes. These results showed that strains OFN $\mathrm{N} 11$ and OFN $\mathrm{N}_{2}{ }^{\mathrm{T}}$ could be distinguished from the type strain of the closest phylogenetic species, $N$. ignorata, by their growth on media containing glycerol, raffinose and sucrose as the sole carbon sources by using conventional methods and the API 50CH system. Some other biochemical

Table 1. Physiological characteristics of strains OFN N12 ${ }^{\top}$ and OFN N11

Strains/species: 1, strain OFN N12 ${ }^{\mathrm{T}}$; 2, strain OFN N11; 3, N. ignorata DSM 44496 ${ }^{\mathrm{T}}$; 4, N. soli DSM 44488 ${ }^{\mathrm{T}}$; 5, N. cummidelens DSM

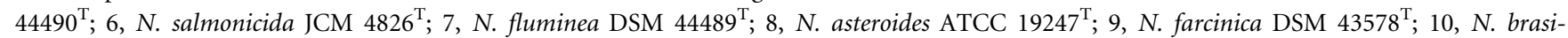
liensis ATCC $19296^{\mathrm{T}} ; 11$, N. pseudobrasiliensis DSM $44290^{\mathrm{T}}$. Data are taken from Isik et al. (1999). All strains were positive in tests for growth on D-glucose $(1.0 \%, \mathrm{w} / \mathrm{v})$ and for growth on Bennett's agar at $25^{\circ} \mathrm{C}$. - , Negative; +, positive; w, weakly positive; ND, not determined.

\begin{tabular}{|c|c|c|c|c|c|c|c|c|c|c|c|}
\hline Characteristic & 1 & 2 & 3 & 4 & 5 & 6 & 7 & 8 & 9 & 10 & 11 \\
\hline \multicolumn{12}{|c|}{ Growth on carbon sources $(\%, w / v)$ : } \\
\hline L-Arabinose (1.0) & - & - & - & - & - & ND & ND & - & - & + & + \\
\hline D-Fructose (1.0) & + & + & + & + & + & $\mathrm{ND}$ & ND & + & + & + & + \\
\hline D-Galactose (1.0) & + & $\mathrm{W}$ & $\mathrm{W}$ & - & - & + & ND & - & + & + & + \\
\hline Glycerol (1.0) & + & + & - & ND & ND & ND & ND & $\mathrm{ND}$ & ND & ND & ND \\
\hline Maltose (1.0) & + & + & + & - & - & - & ND & - & + & + & + \\
\hline D-Mannitol (1.0) & + & + & $\mathrm{W}$ & - & - & ND & - & - & - & $\mathrm{W}$ & + \\
\hline Mannose (1.0) & + & + & + & + & + & ND & ND & + & + & + & + \\
\hline Raffinose (1.0) & + & + & - & - & - & + & ND & - & - & - & - \\
\hline L-Rhamnose (1.0) & - & - & - & - & + & - & + & - & + & - & - \\
\hline D-Ribose (1.0) & + & + & + & + & + & $\mathrm{ND}$ & ND & + & - & + & + \\
\hline Sucrose (1.0) & + & + & - & + & - & $\mathrm{ND}$ & ND & + & + & + & + \\
\hline Sorbitol (1.0) & - & - & - & - & - & + & - & - & - & - & - \\
\hline \multicolumn{12}{|c|}{ Growth on Bennett's agar at: } \\
\hline $37^{\circ} \mathrm{C}$ & + & + & + & + & + & + & ND & + & + & + & + \\
\hline $45^{\circ} \mathrm{C}$ & - & + & - & - & - & - & - & - & + & - & - \\
\hline \multicolumn{12}{|c|}{ Decomposition of $(\%, \mathrm{w} / \mathrm{v})$ : } \\
\hline Adenine (0.4) & - & - & - & - & - & - & - & - & - & - & + \\
\hline Casein $(1.0)$ & - & - & - & - & - & - & - & - & - & - & + \\
\hline Hypoxanthine $(0.4)$ & - & - & - & - & - & - & - & - & - & + & + \\
\hline Testosterone $(0.1)$ & + & + & + & - & - & + & + & + & - & - & - \\
\hline Tyrosine $(0.5)$ & - & - & - & - & - & + & + & - & - & + & + \\
\hline Uric acid $(0.5)$ & - & - & - & - & + & - & - & - & - & - & - \\
\hline
\end{tabular}


properties useful for identifying and differentiating strain OFN $N 12^{\mathrm{T}}$ and the type strains of other species of the genus Nocardia are presented in Table 1 and the species description.

To definitively establish the taxonomic status of the novel strains, the genetic relatedness of strain OFN $\mathrm{N}_{12}{ }^{\mathrm{T}}$ to $N$. ignorata DSM $44496^{\mathrm{T}}$ (taxonomically the closest species based on 16S rRNA sequence similarity) was determined by DNA-DNA hybridization on nylon membranes as described by De Ley et al. (1970), with modifications as described by Huß et al. (1983) and Escara \& Hutton (1980). DNA was isolated by using a French pressure cell and was purified by chromatography on hydroxyapatite as described by Cashion et al. (1977). Renaturation rates were computed with the TRANSFER.BAS program (Jahnke \& Bahnweg, 1986; Jahnke, 1992). The DNA-DNA relatedness of strain OFN N12 ${ }^{\mathrm{T}}$ and $N$. ignorata DSM $44496^{\mathrm{T}}$ was low $(26 \%)$ and well below the $70 \%$ cut-off for species delineation as recommended by Wayne et al. (1987), confirming that strain OFN N12 ${ }^{\mathrm{T}}$ and $N$. ignorata are not related at the species level.

On the basis of the genotypic and phenotypic data described above, it is clear that strains OFN N11 and OFN N12 represent a novel Nocardia species. The name Nocardia coubleae sp. nov. is proposed and isolate OFN N12 $2^{\mathrm{T}}(=\mathrm{CIP}$ $108996^{\mathrm{T}}=\mathrm{DSM} 44960^{\mathrm{T}}$ ) is designated as the type strain.

The results obtained in this study confirm the utility of this multigenic approach (16S rRNA, hsp65, and sod gene sequencing) for the description of Nocardia coubleae sp. nov. and for the description of other novel species belonging to the genus Nocardia in the future.

\section{Description of Nocardia coubleae sp. nov.}

Nocardia coubleae (cou'ble.ae. N.L. gen. n. coubleae of Couble, named after Andrée Couble, in recognition of her contribution to the French Nocardiosis Observatory, Lyon, France).

Cells are Gram-positive, acid-alcohol-fast and strictly aerobic. Colonies on Bennett's agar are rough, $1-2 \mathrm{~mm}$ in diameter and include an orange to white substrate mycelium bearing sparse to abundant white aerial hyphae. Grows at $25^{\circ} \mathrm{C}$ and $37^{\circ} \mathrm{C}$ (optimum at $37^{\circ} \mathrm{C}$ ) and is able to utilize D-glucose, glycerol, raffinose and sucrose as sole carbon sources. Testosterone is decomposed, but adenine, casein, hypoxanthine, tyrosine, uric acid and xanthine are not decomposed. The most abundant fatty acids are palmitic acid $\left(\mathrm{C}_{16: 0}\right), 27.2 \%$ and tuberculostearic acid, $19.8 \%$. Mycolic acids are 52-58 carbon atoms long. The cell-wall chemotype is IV. The main menaquinone is $\mathrm{MK}-8\left(\mathrm{H}_{4 \mathrm{cycl}}\right)$.

The type strain, strain OFN N12 ${ }^{\mathrm{T}}\left(=\mathrm{DSM} 44960^{\mathrm{T}}=\mathrm{CIP}\right.$ $\left.108996^{\mathrm{T}}\right)$, was isolated from Kuwaiti soil.

\section{Acknowledgements}

This work received financial support from Centre National de la Recherche Scientifique (CNRS). V.R.-N. is grateful to Consejo
Nacional de Ciencia y Tecnologia (CONACYT), México City, México, and to the Sociéte Française d'Exportation des Ressources Educatives (SFERE), Paris, France, for their financial support.

\section{References}

Boiron, P., Provost, F. \& Dupont, B. (1993). Technical protocols. In Méthodes de Laboratoire pour le Diagnostic de la Nocardiose, pp. 107-126. Edited by Institut Pasteur. Paris: Institut Pasteur (in French).

Cashion, P., Holder-Franklin, M. A., McCully, J. \& Franklin, M. (1977). A rapid method for the base ratio determination of bacterial DNA. Anal Biochem 81, 461-466.

De Ley, J., Cattoir, H. \& Reynaerts, A. (1970). The quantitative measurement of DNA hybridization from renaturation rates. Eur J Biochem 12, 133-142.

Devulder, G., Perrière, G., Baty, F. \& Flandrois, J. P. (2003). BIBI, a bioinformatics bacterial identification tool. J Clin Microbiol 41, 1785-1787.

Devulder, G., Perouse de Montclos, M. \& Flandrois, J. P. (2005). A multigene approach to phylogenetic analysis using the genus Mycobacterium as a model. Int J Syst Evol Microbiol 55, 293-302.

Escara, J. F. \& Hutton, J. R. (1980). Thermal stability and renaturation of DNA in dimethyl sulphoxide solutions: acceleration of renaturation rate. Biopolymers 19, 1315-1327.

Felsenstein, J. (1981). Evolutionary trees from DNA sequences: a maximum likelihood approach. J Mol Evol 17, 368-376.

Fitch, W. M. (1971). Toward defining the course of evolution: minimum change for a specific tree topology. Syst Zool 20, 406-416.

Galtier, N., Gouy, M. \& Gautier, C. (1996). SEAVIEW and PHYLO_WIN, two graphic tools for sequence alignment and molecular phylogeny. Comput Appl Biosci 12, 543-548.

Goodfellow, M. (1992). The family Nocardiaceae. In The Prokaryotes, 2nd edn, pp. 1188-1213. Edited by A. Balows, H. G. Trüper, M. Dworkin, W. Harder \& K. H. Schleifer. New York: Springer.

Goodfellow, M. (1998). The genus Nocardia Trevisan 1889. In Topley \& Wilson's Microbiology \& Microbial Infections, 9th edn, pp. 464-489. Edited by A. Balows \& B. I. Duerden. London: Edward Arnold.

Goodfellow, M. \& Lechevalier, M. P. (1989). Genus Nocardia Trevisan. In Bergey's Manual of Systematic Bacteriology, vol. 4, pp. 2350-2361. Edited by S. T. Williams, M. E. Sharpe \& J. G. Holt. Baltimore: Williams \& Wilkins.

Huß, V. A. R., Festl, H. \& Schleifer, K. H. (1983). Studies on the spectrophotometric determination of DNA hybridization from renaturation rates. Syst Appl Microbiol 4, 184-192.

Isik, K., Chun, J., Hah, Y. C. \& Goodfellow, M. (1999). Nocardia salmonicida nom. rev., a fish pathogen. Int J Syst Bacteriol 49, 833-837.

Jahnke, K. D. (1992). Basic computer program for evaluation of spectroscopic DNA renaturation data from GILFORD System 2600 spectrometer on a PC/XT/AT type personal computer. J Microbiol Methods 15, 61-73.

Jahnke, K. D. \& Bahnweg, G. (1986). Assessing natural relationships in the Basidiomycetes by DNA analysis. Trans Br Mycol Soc 87, 175-191.

Khan, Z. U., Neil, L., Chandy, R., Chugh, T. D., Al-Sayer, H., Provost, F. \& Boiron, P. (1997). Nocardia asteroides in the soil of Kuwait. Mycopathologia 137, 159-163.

Kroppenstedt, R. M. (1982). Separation of bacterial menaquinones by HPLC using reverse phase (RP-18) and a silver loaded ion exchanger. J Liq Chromatogr 5, 2359-2367. 
Kroppenstedt, R. M. (1985). Fatty acid and menaquinone analysis of actinomycetes and related organisms. In Chemical Methods in Bacterial Systematics (Society for Applied Microbiology Technical Series no. 20), pp. 173-199. Edited by M. Goodfellow \& D. E. Minnikin. London: Academic Press.

Kumar, S., Tamura, K. \& Nei, M. (2004). MEGA3: Integrated software for molecular evolutionary genetics analysis and sequence alignment. Brief Bioinform 5, 150-163.

Kurup, P. V. \& Schmitt, J. A. (1971). Isolation of Nocardia from soil by a modified paraffin bait method. Mycologia 63, 175-177.

Laurent, F. J., Provost, F. \& Boiron, P. (1999). Rapid identification of clinically relevant Nocardia species to genus level by $16 \mathrm{~S}$ rRNA gene PCR. J Clin Microbiol 37, 99-102.

Maldonado, L., Hookey, J. V., Ward, A. C. \& Goodfellow, M. (2000). The Nocardia salmonicida clade, including descriptions of Nocardia cummidelens sp. nov., Nocardia fluminea sp. nov. and Nocardia soli sp. nov. Antonie van Leeuwenhoek 78, 367-377.

Minnikin, D. E., Alshamaony, L. \& Goodfellow, M. (1975). Differentiation of Mycobacterium, Nocardia, and related taxa by thin-layer chromatographic analyses of whole-cell methanolysates. J Gen Microbiol 88, 200-204.

Minnikin, D. E., O'Donnell, A. G., Goodfellow, M., Alderson, G., Athalye, M., Schaal, A. \& Parlett, J. H. (1984). An integrated procedure for the extraction of isoprenoid quinones and polar lipids. J Microbiol Methods 2, 233-241.

Nocard, M. E. (1888). Note sur la maladie des boeufs de la guadeloupe connue sous le nom de farcin. Ann Inst Pasteur (Paris) 2, 293-302.

Rodríguez-Nava, V., Couble, A., Molinard, C., Sandoval, H., Boiron, P. \& Laurent, F. (2004). Nocardia mexicana sp. nov., a new pathogen isolated from human mycetomas. J Clin Microbiol 42, 4530-4535.

Rodríguez-Nava, V., Couble, A., Khan, Z. U., Pérouse de Montclos, M., Brasme, L., Villuendas, C., Molinard, C., Boiron, P. \& Laurent, F. (2005). Nocardia ignorata, a new agent of human nocardiosis isolated from respiratory specimens in Europe and soil samples from Kuwait. J Clin Microbiol 43, 6167-6170.

Rodríguez-Nava, V., Couble, A., Devulder, G., Flandrois, J.-P., Boiron, P. \& Laurent, F. (2006). Use of PCR-restriction enzyme pattern analysis and sequencing database for $h s p 65$ gene-based identification of Nocardia species. J Clin Microbiol 44, 536-546.

Roth, A., Andrees, S., Kroppenstedt, R. M., Harmsen, D. \& Mauch, H. (2003). Phylogeny of the genus Nocardia based on reassessed $16 \mathrm{~S}$ rRNA gene sequences reveals underspeciation and division of strains classified as Nocardia asteroides into three established species and two unnamed taxons. J Clin Microbiol 41, 851-856.

Saitou, N. \& Nei, M. (1987). The neighbor-joining method: a new method for reconstructing phylogenetic trees. Mol Biol Evol 4, 406-425.

Stackebrandt, E., Rainey, F. A. \& Ward-Rainey, N. L. (1997). Proposal for a new hierarchic classification system, Actinobacteria class nov. Int J Syst Bacteriol 47, 479-491.

Steingrube, V. A., Wilson, R. W., Brown, B. A., Jost, K. C., Jr, Blacklock, Z., Gibson, J. L. \& Wallace, R. J., Jr (1997). Rapid identification of clinically significant species and taxa of aerobic actinomycetes, including Actinomadura, Gordona, Nocardia, Rhodococcus, Streptomyces, and Tsukamurella isolates, by DNA amplification and restriction endonuclease analysis. J Clin Microbiol 35, 817-822.

Thompson, J. D., Gibson, T. J., Plewniak, F., Jeanmougin, F. \& Higgins, D. G. (1997). The CLUSTAL_X windows interface: flexible strategies for multiple sequence alignment aided by quality analysis tools. Nucleic Acids Res 25, 4876-4882.

Wayne, L. G., Brenner, D. J., Colwell, R. R., Grimont, P. A. D., Kandler, O., Krichevski, M. I., Moore, L. H., Moore, W. E. C., Murray, R. G. E., Stackebrandt, E., Starr, M. P. \& Trüper, H. G. (1987). International Committee on Systematic Bacteriology. Report of the ad hoc committee on reconciliation of approaches to bacterial systematics. Int J Syst Bacteriol 37, 463-464. 